Retraction

\title{
Retracted: The Parenteral Vitamin C Improves Sepsis and Sepsis- Induced Multiple Organ Dysfunction Syndrome via Preventing Cellular Immunosuppression
}

\author{
Mediators of Inflammation \\ Received 4 July 2020; Accepted 14 July 2020; Published 4 September 2020 \\ Copyright (C) 2020 Mediators of Inflammation. This is an open access article distributed under the Creative Commons Attribution \\ License, which permits unrestricted use, distribution, and reproduction in any medium, provided the original work is \\ properly cited.
}

Mediators of Inflammation has retracted the article titled "The Parenteral Vitamin C Improves Sepsis and SepsisInduced Multiple Organ Dysfunction Syndrome via Preventing Cellular Immunosuppression" [1] due to figure duplication between articles by the same authors.

Figure duplication concerns were raised to our attention and then noted on PubPeer [2]. A reassessment of the article concluded that a number of panels in Figure 2(g) of [1] were duplicates of panels in Figure 1 of [3]. Duplications were also identified in another article [4], where the fourth panel of Figure 5(e) in [1] duplicates the third panel of Figure $8(\mathrm{~b})$ in [4].

The authors did not provide a satisfactory response and the article is therefore being retracted with the agreement of the Chief Editor. The authors do not agree to the retraction.

\section{References}

[1] Y.-L. Gao, B. Lu, J.-H. Zhai et al., “The Parenteral Vitamin C Improves Sepsis and Sepsis-Induced Multiple Organ Dysfunction Syndrome via Preventing Cellular Immunosuppression," Mediators of Inflammation, vol. 2017, 12 pages, 2017.

[2] PubPeer 2018, https://pubpeer.com/publications/5EB78957 D481A43893D38764FB3118.

[3] Y.-L. Gao, Y.-F. Chai, A.-L. Qi et al., "Neuropilin-1highCD4 +CD25+ Regulatory T Cells Exhibit Primary Negative Immunoregulation in Sepsis," Mediators of Inflammation, vol. 2016, Article ID 7132158, 11 pages, 2016.

[4] Y.-L. Gao, M.-M. Yu, S.-T. Shou et al., "Tuftsin prevents the negative immunoregulation of neuropilin-1highCD4+CD25 +regulatory T cells and improves survival rate in septic mice," Oncotarget, vol. 7, no. 49, pp. 81791-81805, 2016. 


\title{
The Parenteral Vitamin C Improves Sepsis and Sepsis-Induced Multiple Organ Dysfunction Syndrome via Preventing Cellular Immunosuppression
}

\author{
Yu-Lei Gao, Bin Lu, Jian-Hua Zhai, Yan-Cun Liu, Hai-Xia Qi, Ying Yao, \\ Yan-Fen Chai, and Song-Tao Shou \\ Department of Emergency Medicine, Tianjin Medical University General Hospital, Tianjin 300052, China \\ Correspondence should be addressed to Yu-Lei Gao; gaoyulei828@126.com and Song-Tao Shou; stshou66@sina.com
}

Received 11 October 2016; Revised 21 December 2016; Accepted 27 December 2016; Published 22 January 2017

Academic Editor: Mirella Giovarelli

Copyright (c) 2017 Yu-Lei Gao et al. This is an open access article distributed under the Creative Commons Attribution License, which permits unrestricted use, distribution, and reproduction in any medium, provided the original work is properly cited.

Cellular immunosuppression appears to be involved in sepsis and sepsis-induced multiple organ dysfunction syndrome (MODS). Recent evidence showed that parenteral vitamin C (Vit C) had the ability to attenuate sepsis and sepsis-induced MODS. Herein, we investigated the impact of parenteral Vit $\mathrm{C}$ on cellular immunosuppression and the therapeutic value in sepsis. Using cecal ligation and puncture (CLP), sepsis was induced in WT and Gulo ${ }^{-1-}$ mice followed with $200 \mathrm{mg} / \mathrm{Kg}$ parenteral Vit C administration. The immunologic functions of $\mathrm{CD}^{+} \mathrm{CD} 25^{+}$regulatory $\mathrm{T}$ cells (Tregs) and $\mathrm{CD} 4^{+} \mathrm{CD} 25^{-} \mathrm{T}$ cells, as well as the organ functions, were determined. Administration of parenteral Vit C per se markedly improved the outcome of sepsis and sepsis-induced MODS of WT and $\mathrm{Gulo}^{-1-}$ mice. The negative immunoregulation of Tregs was inhibited, mainly including inhibiting the expression of forkhead helix transcription factor- (Foxp-) 3, cytotoxic T lymphocyte associated antigen- (CTLA-) 4, membrane associated transforming growth factor- $\beta$ (TGF- $\beta^{\mathrm{m}+}$ ), and the secretion of inhibitory cytokines [including TGF- $\beta$ and interleukin- (IL-) 10], as well as CD4 ${ }^{+}$ T cells-mediated cellular immunosuppression which was improved by parenteral Vit C in WT and Gulo ${ }^{-/-}$septic mice. These results suggested that parenteral Vit $\mathrm{C}$ has the ability to improve the outcome of sepsis and sepsis-induced MODS and is associated with improvement in cellular immunosuppression.

\section{Introduction}

Sepsis, which is defined as the life-threatening organ dysfunction caused by the dysregulated host response to infection, is the leading cause of MODS and death among critically ill patients [1-4]. There was a significant loss of immunocytes, mainly including B/T-lymphocytes and gastrointestinal epithelial cells, even at the beginning of sepsis [5-8]. It has been noted that patients gradually enter into a state of immunosuppression after primary hyperinflammatory response, especially cellular immunosuppression, defined as immunoparalysis, which could be a significant cause of the exacerbation of MODS or even death out of sepsis $[2,4]$. More and more researches showed that modulating the immunosuppressive stage might be a promising interventional strategy to improve the outcome of sepsis [9]. With sepsis, Tregs subdued the process of inflammation and tissue damage while also causing immune dysfunction, including induction of T-lymphocytic apoptosis, inhibition of $\mathrm{CD}^{+} / \mathrm{CD}^{+}$T-lymphocytic function, and mediation of shifting from the helper $\mathrm{T}$ cell (Th) 1 to Th 2 response via the expression of CTLA- 4 and TGF- $\beta^{\mathrm{m}+}$, as well as antiinflammatory cytokines (IL-10 and TGF- $\beta$ ) [10-15].

Vit $\mathrm{C}$, characterized as essential endogenous trace element and important physiological antioxidant, is involved in the incidence of sepsis and sepsis-induced MODS, even directly with the survival of septic patients $[16,17]$. Vit C is identified as an essential component of the immunological response in humanity and experimental animals which augmented a variety of immune reaction, such as the development of mouse bone marrow derived progenitor cells to functional B/T-lymphocytes, the balance of Th1/Th2 response, and the increased serum levels of $\operatorname{IgA}$ and $\operatorname{IgM}$, as well as regulating the balance of proliferation and apoptosis 
of $\mathrm{T}$ cells [18-21]. In addition, treatment with Vit $\mathrm{C}$ was correlated with the expression of Foxp-3, the demethylation of Foxp3-TSDR (Treg-specific demethylated region), and the suppressive capacity of Tregs in vitro [22]. Yet, direct effects of Vit $\mathrm{C}$ on sepsis-induced cellular immunosuppression are not known. Thus, further investigating the impact of Vit C on sepsis-induced cellular immunosuppression will provide a new evidence for understanding the mechanisms of Vit C in the treatment of sepsis. Humanity completely powerlessly synthesizes Vit $\mathrm{C}$ on account of the deficiency of L-gulono$\gamma$-lactone oxidase (Gulo), which is the pivotal enzyme in the biosynthesis of Vit C; therefore we conducted studies in transgenic mice lacking Gulo $4\left(\mathrm{Gulo}^{-/-}\right)$, to investigate the impact of parenteral Vit $\mathrm{C}$ on cellular immunosuppression in sepsis and sepsis-induced MODS.

In the present study, using the classical septic model, that is, CLP, we demonstrated that administration of parenteral Vit C per se markedly improved the outcome of sepsis and sepsis-induced MODS of WT and $\mathrm{Gulo}^{-/-}$mice. The negative immunoregulation of Tregs was inhibited, mainly including decreasing the expression of Foxp-3, CTLA- 4 , and TGF- $\beta^{\text {m+ }}$ and the secretion of inhibitory cytokines (TGF- $\beta$ and IL10), as well as improving $\mathrm{CD}^{+} \mathrm{T}$ cells-mediated cellular immunosuppression by parenteral Vit C in WT and Gulo ${ }^{-1-}$ septic mice. These results suggested that parenteral Vit C has the ability to improve the outcome of sepsis and sepsisinduced MODS and associate with improvement in cellular immunosuppression.

\section{Materials and Methods}

2.1. Animals. The Gulo ${ }^{-/-} \mathrm{C} 57 \mathrm{BL} / 6 \mathrm{~J}$ mice were propagated from heterozygous $\mathrm{Gulo}^{+/-} \mathrm{C} 57 \mathrm{BL} / 6 \mathrm{~J}$ mice which were picked up from The Mutant Mouse Regional Resource Center (https://www.mmrrc.org/,No. 000015-UCD) and were maintained on a C57BL/6J background (The Laboratory Animal Center of Chinese Academy of Medical Sciences, number SCXK-Jing-2009-0007, Beijing, China). The WT and Gulo ${ }^{-/-}$ C57BL/6J mice, 6-8 weeks old, $20 \pm 2 \mathrm{~g}$, were maintained in a specific pathogen-free condition. They were maintained for about 1 week with Vit C supplementation $(3.3 \mathrm{~g} / \mathrm{L}$, picked up from Luwei Pharmacy, Jinan, Shan Dong, China) in their drinking water. All procedures were undertaken in accordance with the National Institute of Health Guide for the Care and Use of Laboratory Animal and approved by the Scientific Investigation Board and Tianjin Medical University General Hospital, Tianjin, China.

2.2. Medium and Reagents. The medium was RPMI1640 (Nanjing Keygen Biotech, Nanjing, China) with 10\% fetal bovine serum (FBS, Sigma, St. Louis, MO). CD ${ }^{+} \mathrm{CD} 25^{+}$ Tregs isolation kits were from Miltenyi Biotec $\mathrm{GmbH}$, Bergisch Gladbach, Germany. Cell counting kit-8 (CCK-8) was from Dojindo, Kumamoto, Japan. Fluorescein isothiocyanate- (FITC-) conjugated Annexin-V apoptotic kit, purified hamster anti-mouse CD3/CD28, FITC-conjugated antimouse CTLA-4, FITC-conjugated anti-mouse/rat-Foxp-3, and allophycocyanin- (APC-) conjugated anti-mouse/ratTGF- $\beta^{\mathrm{m}+}$ were from eBioscience, San Diego, CA. ELISA kits for interferon- (IFN-) $\gamma$, IL-4, IL-10, and TGF- $\beta$ were from Excell Biol, Shanghai, China. Alanine transaminase (ALT), aspartate transaminase (AST), creatinine (Cr), and arterial blood gas $(\mathrm{ABG})$ kits were from Instrumentation Laboratory Company, MA, USA. All primers and SYBR Green Real-Time Polymerase Chain Reaction (RT-PCR) Master Mix were from Applied Biosystems, Carlsbad, CA.

2.3. Isolation of Splenic $C D 4^{+} C D 25^{+}$Tregs and $C D 4^{+} C D 25^{-}$ $T$ Cells. $\mathrm{CD} 4^{+} \mathrm{CD} 25^{+}$Tregs and $\mathrm{CD} 4^{+} \mathrm{CD} 25^{-} \mathrm{T}$ cells were isolated using mouse $\mathrm{CD} 4^{+} \mathrm{CD} 25^{+}$Tregs isolation kits, which we have recounted $[23,24]$.

2.4. Sepsis Model. The classical septic model, that is, CLP, is used which we have recounted in our previous studies to induce sepsis $[23,24]$.

2.5. Experimental Design. 180 mice were divided into control group (30 mice), WT mice with CLP group [WT (CLP), 50 mice], WT mice with CLP and subcutaneous injection of $200 \mathrm{mg} / \mathrm{Kg}$ parenteral Vit C group [WT (CLP + Vit C), 50 mice], Gulo ${ }^{-/-}$mice with CLP group $\left[\mathrm{Gulo}^{-/-}\right.$(CLP), 50 mice], and Gulo-/- mice with CLP and subcutaneous injection of $200 \mathrm{mg} / \mathrm{Kg}$ parenteral Vit C group [Gulo ${ }^{-/-}$(CLP + Vit C), 50 mice]. The first administration time of parenteral Vit C was immediately after CLP, and parenteral Vit C was given again after 12 hours. The survival time and rate were recorded for 72 hours in various groups. $\mathrm{CD} 4{ }^{+} \mathrm{CD} 25^{+}$Tregs and $\mathrm{CD} 4^{+} \mathrm{CD} 25^{-} \mathrm{T}$ cells were isolated from every group at the point of 24 hours after CLP. The proliferative activity, apoptotic rate, and secretion ability (including IFN- $\gamma$ and IL-4) of $\mathrm{CD}^{+}{ }^{+} \mathrm{CD} 25^{-} \mathrm{T}$ cells, as well as the expression of Foxp-3, Foxp3-TSDR, Helios, CTLA-4, TGF- $\beta^{\mathrm{m}+}$, apoptotic rate, and secretion ability (including IL-10 and TGF- $\beta$ ) of $\mathrm{CD} 4{ }^{+} \mathrm{CD} 25^{+}$Tregs, were determined. The serum levels of AST, ALT, and Cr, as well as ABG, were determined by The Central Laboratory of Tianjin Medical University General Hospital.

2.6. Flow Cytometric Analysis. The expression levels of Foxp-3, CTLA-4, and TGF- $\beta^{\mathrm{m}+}$ of $\mathrm{CD} 4^{+} \mathrm{CD} 25^{+}$Tregs, as well as the apoptotic rates of $\mathrm{CD} 4^{+} \mathrm{CD} 25^{+}$Tregs and $\mathrm{CD} 4{ }^{+} \mathrm{CD} 25^{-} \mathrm{T}$ cells, were determined by flow cytometer (Becton-Dickinson), which we have recounted [23, 24].

2.7. CCK-8 Measurement. The proliferative ability of $\mathrm{CD} 4^{+} \mathrm{CD} 25^{-} \mathrm{T}$ cells was determined by CCK-8, which we have recounted $[23,24]$.

2.8. SYBR Green and Methylation-Sensitive RT-PCR. $1 \times 10^{6}$ cells/group were used for distilling the total RNA via the single technique of acid guanidinium thiocyanate-chloroform extraction according to the manufacturer's instruction. The mRNA expressions of Foxp-3, Helios, CTLA-4, TGF- $\beta$, and IL-10 were tested by SYBR Green RT-PCR. The primer 
TABLE 1: Targeted genes and their primer sequences for SYBR Green and Methylation-Sensitive Real-Time Polymerase Chain Reaction.

\begin{tabular}{|c|c|}
\hline Gene & Primer sequences \\
\hline Mouse Foxp-3 & $\begin{array}{l}\text { Forward: 5'-CAGCTGCCTACAGTGCCCCTAG-3 } \\
\text { Reverse: } 5^{\prime} \text {-CATTTGCCAGCAGTGGGTAG-3' }\end{array}$ \\
\hline Mouse Helios & $\begin{array}{l}\text { Forward: 5' -TAAGCTCAGCTTATTCTCAGGTCTATCA-3' } \\
\text { Reverse: } 5^{\prime} \text {-ATGTTGTTTTCGTGACTATCAGATGTT-3' }\end{array}$ \\
\hline Mouse CTLA-4 & $\begin{array}{l}\text { Forward: } 5^{\prime} \text {-CGCAGATTTATGTCATTGATCC-3' } \\
\text { Reverse: } 5^{\prime} \text {-TTTTCACATAGACCCCTGTTGT-3' }\end{array}$ \\
\hline Mouse IL-10 & $\begin{array}{l}\text { Forward: 5'-ACAGCCGGGAAGACAATAAC-3' } \\
\text { Reverse: } 5^{\prime} \text {-CAGCTGGTCCTTTGTTTGAAAG-3' }\end{array}$ \\
\hline Mouse Foxp3-TSDR & $\begin{array}{l}\text { Forward: 5' -CTTGCTTCCTGGCACGAGATTTGAATTGGATATGGTTTGT-3' } \\
\text { Reverse: } 5^{\prime} \text {-CAGGAAACAGCTATGACAACCTTAAACCCCTCTAACATC-3 }\end{array}$ \\
\hline
\end{tabular}

sequences were listed in Table 1 . The amplification of PCR consisted of $1 \mathrm{~min}$ denaturation step at $95^{\circ} \mathrm{C}$ followed by 40 cycles of $15 \mathrm{~s}$ at $95^{\circ} \mathrm{C}$ and $40 \mathrm{~s}$ at $60^{\circ} \mathrm{C}$ using the Sequence Detection System (Applied Biosystems). The methylation level of Foxp3-TSDR was determined by MethylationSensitive RT-PCR, which has been recounted by Tatura et al. [11]. The primers for Foxp3-TSDR were listed in Table 1.

2.9. ELISA Measurement. The levels of IFN- $\gamma$, IL-4, IL-10, and TGF- $\beta$ were determined by ELISA kits, strictly according to the protocols provided by manufacturer, using microplate reader at OD 450.

2.10. Statistical Analysis. Data were represented as mean \pm standard deviation (SD) and analyzed by software SPSS 17.0 with one-way ANOVA. Unpaired Student's $t$-test was used to evaluate significant differences between groups. A $p$ value of 0.05 or 0.01 was considered statistically significant. Survival rate in septic mice was evaluated by Kaplan-Meier via the logrank test.

\section{Results}

3.1. Parenteral Vit C Improved the Outcome of Sepsis and Sepsis-Induced MODS. As shown in Figure 1(a), compared with WT (CLP) group, the deficiency of Vit C reduced the 72-hour survival rate of $\mathrm{Gulo}^{-/-}$mice $(p<0.05)$; administration of parenteral Vit $C$ significantly increased the survival rate of WT and Gulo ${ }^{-1-}$ mice $(p<0.01)$ in sepsis. Compared with WT (CLP) group at 24 hours after CLP, the deficiency of Vit $\mathrm{C}$ worsened the organs function of $\mathrm{Gulo}^{-/-}$(CLP) mice with sepsis, acting as the serum levels of AST (Figure 1(b)), ALT (Figure 1(c)), Cr (Figure 1(d)), and Lac (Figure $1(\mathrm{~g})$ ) were elevated, but the levels of $\mathrm{PCO}_{2}$ (Figure 1(e)) and $\mathrm{PO}_{2}$ (Figure 1(f)) were decreased $(p<$ 0.05 or 0.01 ); administration of parenteral Vit C after CLP significantly improved the appellate quotas of organ function of WT mice and Gulo ${ }^{-/-}$mice $(p<0.05$ or 0.01$)$.

3.2. Parenteral Vit $C$ Weakened the Stability of $C D 4^{+} C D 25^{+}$ Tregs with Sepsis. $\mathrm{CD} 4^{+} \mathrm{CD} 25^{+}$Tregs were isolated from every group; the deficiency of Vit $\mathrm{C}$ inhibited the expression of Foxp-3 (Figure 2(a)), CTLA-4 (Figure 2(b)), and TGF- $\beta^{\mathrm{m}+}$ (Figure 2(c)) on splenic CD $4^{+} \mathrm{CD} 25^{+}$Tregs of Gulo ${ }^{-/-}$mice ( $p<0.05$ or 0.01 ), but the expressions of Foxp-3, CTLA-4, and TGF- $\beta^{\mathrm{m}+}$ were significantly weakened when parenteral Vit $C$ was administered after CLP to WT mice and Gulo-/mice $(p<0.05$ or 0.01$)$. Figure $2(\mathrm{~d})$ showed that there were no differences between WT and Gulo ${ }^{-1-}$ mice on the apoptotic level of $\mathrm{CD} 4^{+} \mathrm{CD} 25^{+}$Tregs, with or without administered parenteral Vit $C$ with sepsis $(p>0.05)$. The supernatant levels of TGF- $\beta$ (Figure 2(e)) and IL-10 (Figure 2(f)) were significantly increased from $\mathrm{CD} 4{ }^{+} \mathrm{CD} 25^{+}$Tregs which were isolated from $\mathrm{Gulo}^{-/-}$(CLP) groups after being cultured for 24 hours $(p<0.01)$ but significantly decreased from $\mathrm{CD} 4^{+} \mathrm{CD} 25^{+}$ Tregs which were isolated from WT and Gulo ${ }^{-/-}$mice with administration of parenteral Vit $C(p<0.05$ or 0.01$)$.

3.3. Parenteral Vit $C$ Inhibited the Immunosuppressive Function of $\mathrm{CD}^{+} \mathrm{CD} 25^{+}$Tregs. $\mathrm{CD} 4^{+} \mathrm{CD} 25^{+}$Tregs were cocultured with conventional $\mathrm{CD} 4^{+} \mathrm{CD} 25^{-} \mathrm{T}$ cells for another 24 hours in a ratio of $1: 1$ with anti-CD3 $(5 \mu \mathrm{g} / \mathrm{mL})$ and anti-CD28 $(2 \mu \mathrm{g} / \mathrm{mL})$ for polyclonal activation of $\mathrm{T}$ cells, respectively. $\mathrm{CD} 4{ }^{+} \mathrm{CD} 25^{+}$Tregs which were isolated from $\mathrm{Gulo}^{-/-}$(CLP) group significantly inhibited the proliferative activity (Figure 3(a)) and release of IFN- $\gamma$ (Figure 3(c)) but enhanced the apoptotic rate (Figure $3(\mathrm{~b})$ ) and release of IL-4 (Figure $3(\mathrm{~d}))$ of $\mathrm{CD} 4^{+} \mathrm{CD} 25^{-} \mathrm{T}$ cells $(p<0.05$ or 0.01 ); however, treatment with parenteral Vit C of WT and $\mathrm{Gulo}^{-/-}$mice significantly inhibited the immunosuppressive function of $\mathrm{CD} 4^{+} \mathrm{CD} 25^{+}$Tregs to $\mathrm{CD} 4^{+} \mathrm{CD} 25^{-} \mathrm{T}$ cells which increased the proliferative response and release of IFN- $\gamma$ but decreased the apoptotic rate and release of IL-4 of conventional $\mathrm{CD} 4^{+} \mathrm{CD} 25^{-} \mathrm{T}$ cells $(p<0.05$ or 0.01$)$.

3.4. The Impact of Parenteral Vit $C$ on the $m R N A$ Expression of Foxp-3, Helios, CTLA-4, TGF- $\beta, I L-10$, and the Methylation Level of Foxp3-TSDR. The deficiency of Vit C significantly promoted the mRNA expression of Foxp-3 (Figure 4(a)), Helios (Figure 4(c)), CTLA-4 (Figure 4(d)), $T G F-\beta$ (Figure 4(e)), and $I L-10$ (Figure 4(f)) but decreased the methylation level of Foxp3-TSDR (Figure 4(b)) in 


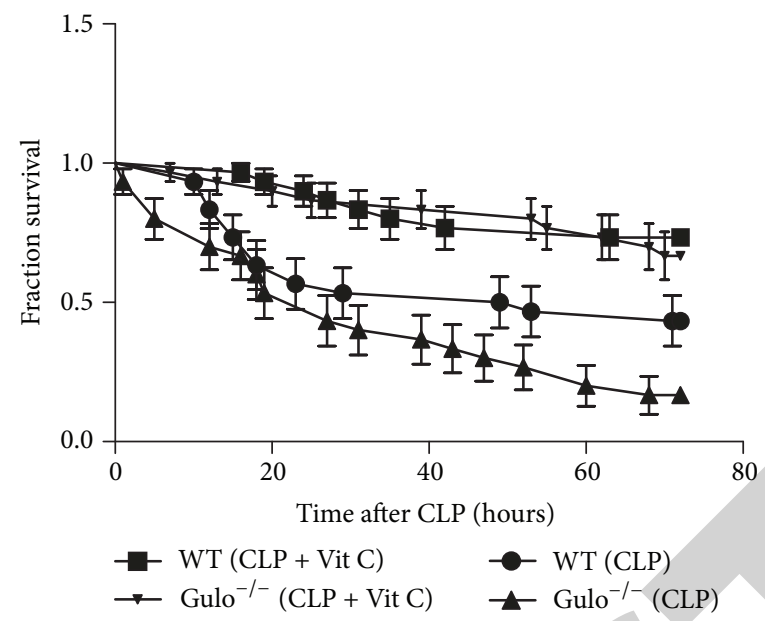

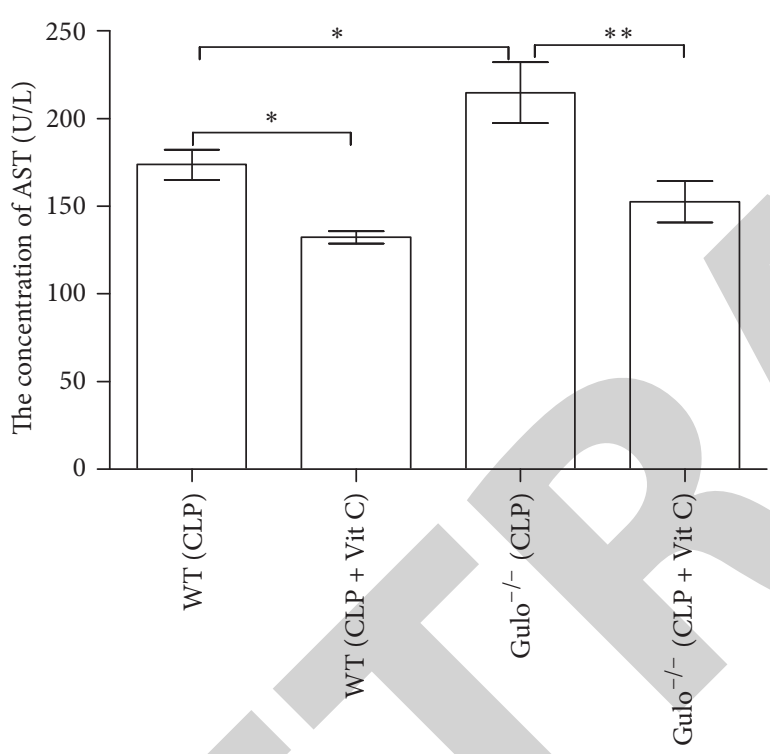

(b)

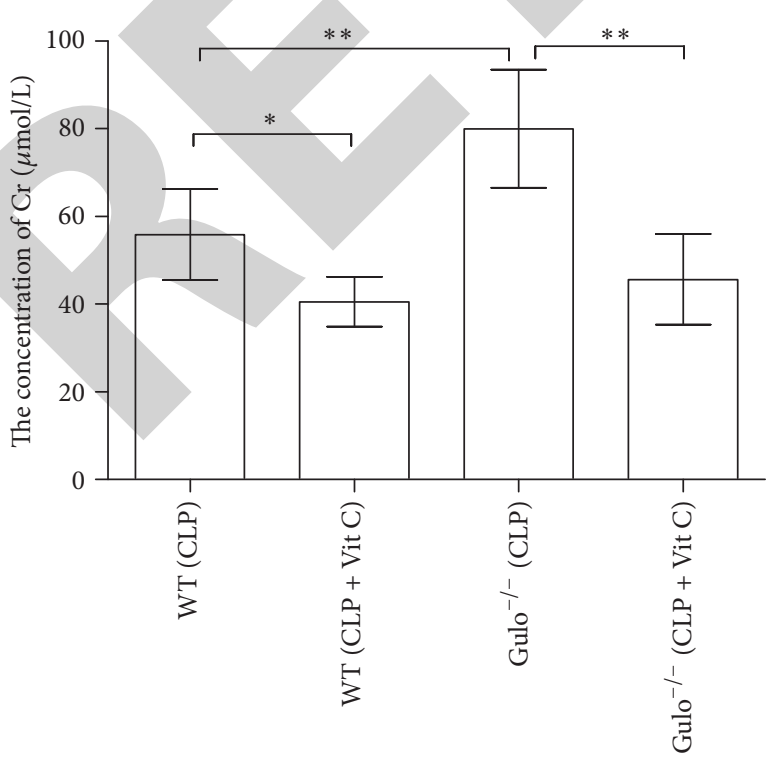

(d)

(a)

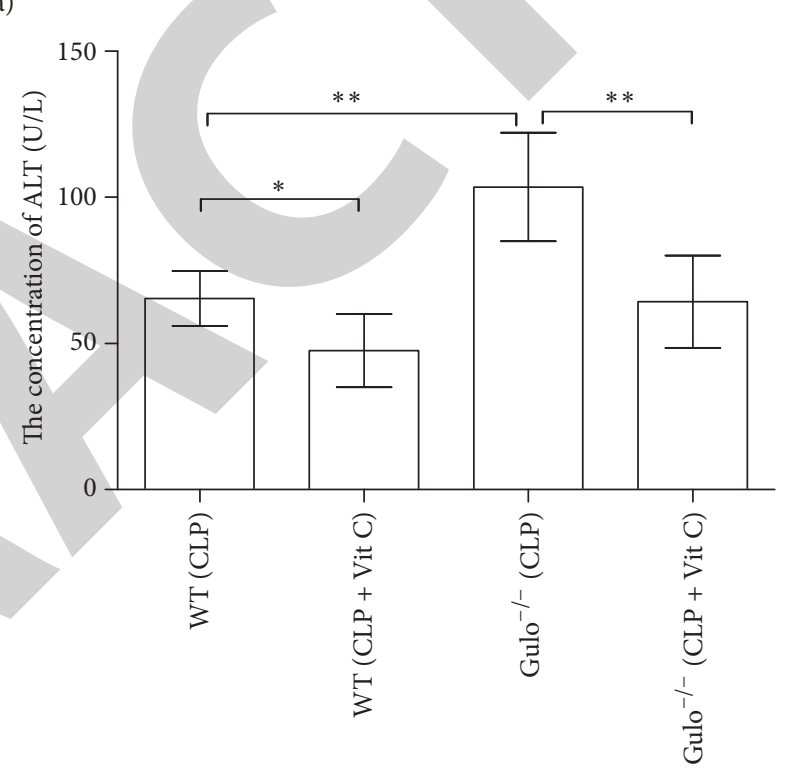

(c)

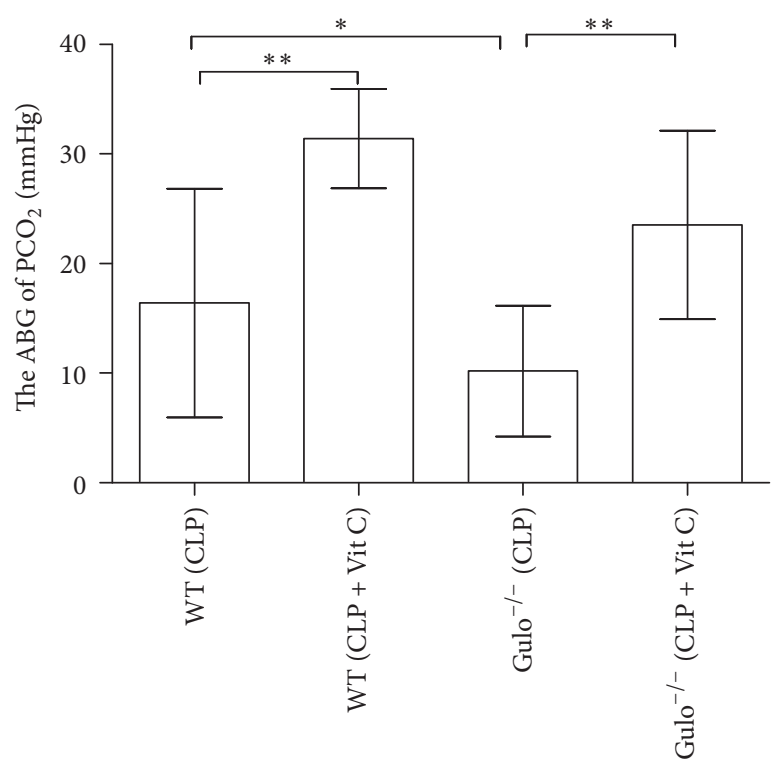

(e)

Figure 1: Continued. 

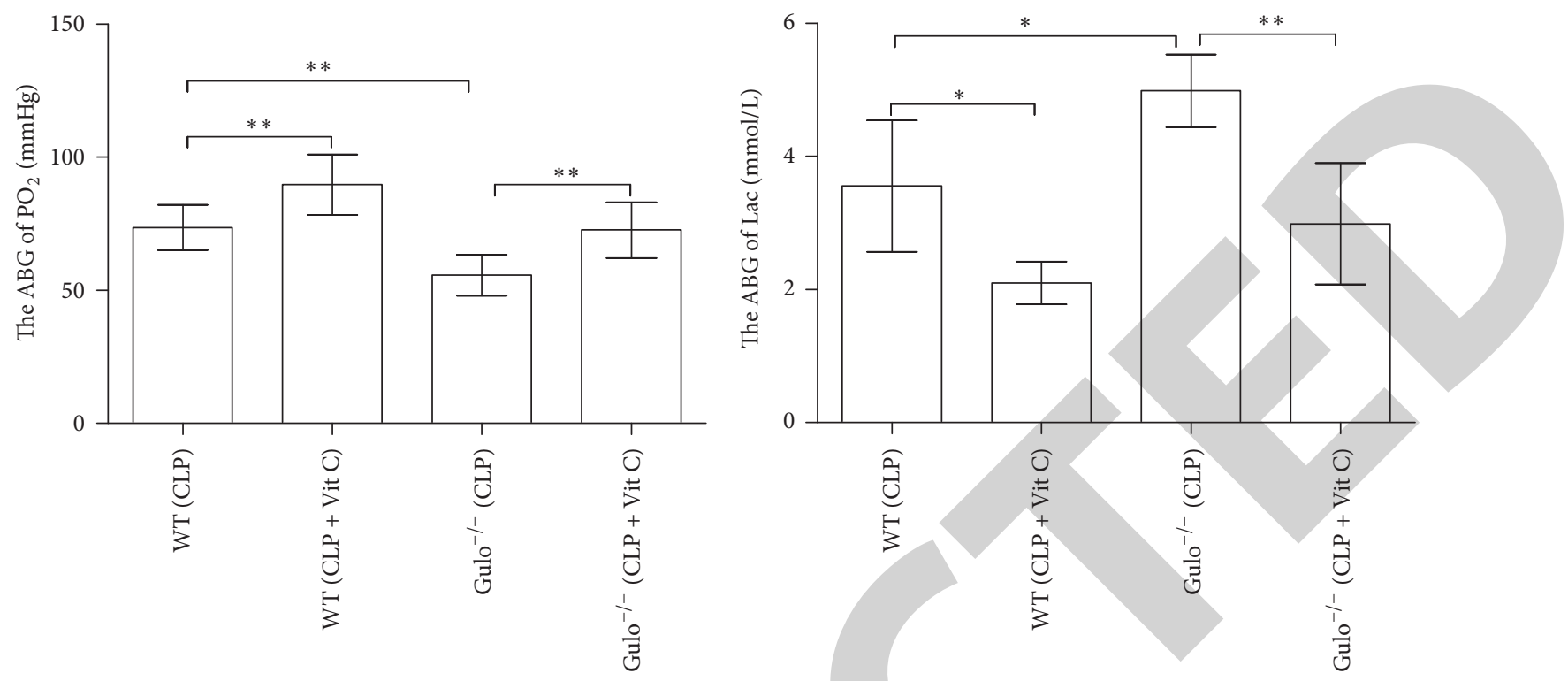

(f)

(g)

Figure 1: The impact of parenteral Vit C treatment on the 72-hour survival rate of septic mice and sepsis-induced MODS. The 72-hour survival rate of WT mice and $\mathrm{Gulo}^{-/-}$mice was improved on administration of $200 \mathrm{mg} / \mathrm{Kg}$ parenteral Vit C twice after CLP (a). Parenteral Vit $\mathrm{C}$ improved the biomarkers of liver $(\mathrm{b}$ and $\mathrm{c}$ ), renal $(\mathrm{d})$, respiratory (e and $\mathrm{f}$ ), and circulatory $(\mathrm{g})$ function in CLP-exposed WT mice and Vit $\mathrm{C}$ deficient Gulo ${ }^{-/-}$mice. The survival rate was analyzed by Kaplan-Meier via the log-rank test, $n=50$ per group. WT (CLP) versus WT $(\mathrm{CLP}+\mathrm{Vit} \mathrm{C}), p<0.01 \mathrm{Gulo}^{-/-}$(CLP) versus Gulo ${ }^{-/-}(\mathrm{CLP}+\mathrm{Vit} \mathrm{C}), p<0.01$. WT (CLP) versus Gulo ${ }^{-/-}(\mathrm{CLP}), p<0.05$. Data were represented as mean \pm standard deviation (SD) and analyzed by software SPSS 17.0 with one-way ANOVA, $n=4$ per group, ${ }^{*} p<0.05$ or ${ }^{* *} p<0.01$.

$\mathrm{CD} 4{ }^{+} \mathrm{CD} 25^{+}$Tregs of Gulo ${ }^{-/-}$(CLP) group in comparison to WT (CLP) group $(p<0.01)$. Treatment with parenteral Vit C after CLP of WT and Gulo ${ }^{-1-}$ mice inhibited the expression of Foxp-3, Helios, CTLA-4, TGF- $\beta$, and IL-10 but enhanced the methylation level of Foxp3-TSDR in $\mathrm{CD} 4{ }^{+} \mathrm{CD} 25^{+}$Tregs $(p<0.05$ or 0.01$)$.

3.5. Parenteral Vit C Improved CD $4^{+}$T Cells-Mediated Cellular Immunosuppression. $\mathrm{CD} 4^{+} \mathrm{CD} 25^{-} \mathrm{T}$ cells were isolated from every group and cultured for another 24 hours. The deficiency of Vit C significantly worsened the proliferative ability (Figure 5(a)) and IFN- $\gamma$ level (Figure 5(c)) but increased the release of IL-4 (Figure $5(\mathrm{~d})$ ) of splenic CD $4^{+} \mathrm{CD} 25^{-} \mathrm{T}$ cells of $\mathrm{Gulo}^{-/-}$mice $(p<0.01)$; however, treatment with parenteral Vit C after CLP significantly enhanced the proliferative response and IFN- $\gamma$ level but inhibited the release of IL4 of $\mathrm{CD} 4^{+} \mathrm{CD} 25^{-} \mathrm{T}$ cells of WT and Gulo ${ }^{-/-}$mice $(p<0.01)$. As shown in Figure 5(b), the deficiency of Vit $C$ significantly increased the apoptotic rate of splenic $\mathrm{CD} 4^{+} \mathrm{CD} 25^{-} \mathrm{T}$ cells of $\mathrm{Gulo}^{-/-}$mice $(p<0.01)$; however, treatment with parenteral Vit C after CLP decreased the apoptotic rate of CD $4^{+} \mathrm{CD} 25^{-}$ T cells of WT mice and Gulo ${ }^{-/-}$mice with sepsis $(p<0.05$ or 0.01$)$.

\section{Discussion}

MODS is the principal cause of death in critically ill patients with sepsis [3]. Fisher BJ and his colleagues showed that low circulatory level of Vit C was significantly susceptible to sepsis-induced MODS [16]. In the current study, we reported that administration of parenteral Vit $\mathrm{C}$ per se markedly improved sepsis and sepsis-induced MODS in WT and $\mathrm{Gulo}^{-/-}$mice, which was in accordance with the findings of Fisher BJ. Meanwhile, we first reported the mechanisms of parenteral Vit $\mathrm{C}$ in improving the outcome of sepsis and sepsis-induced MODS via regulating cellular immunosuppression.

The immune dysfunction of $\mathrm{CD} 4^{+} \mathrm{T}$ cells is the primary cellular mechanisms with sepsis and sepsis-induced MODS. Immediate specimens from liver, kidney, and lung, even the cellular number of circulatory system in septic patients who died in intensive care units, showed a progressive, profound, apoptosis-induced loss of adaptive immunocytes, especially the early decrease of T-lymphocytes, thereby resulting in an attenuated ability of clearing life-threatening pathogens $[2,5,7,8]$. The activated $\mathrm{CD} 4^{+} \mathrm{T}$ cells can mainly differentiate into Th1 and Th2 which mainly produced IFN- $\gamma$ and IL-4, respectively. A shift to Th2 response was noted to be corroborated with sepsis-induced MODS and the outcome of sepsis $[8,20,25,26]$. We showed that administration of parenteral Vit $C$ had the ability to improve the immune dysfunction of $\mathrm{CD}^{+}{ }^{+} \mathrm{T}$ cells. Sepsis significantly weakened the proliferation and IFN- $\gamma$ secretion but enhanced the apoptotic level and IL4 secretion of $\mathrm{CD} 4^{+} \mathrm{CD} 25^{-} \mathrm{T}$ cells of WT mice and $\mathrm{Gulo}^{-/-}$ mice; however, treatment with $200 \mathrm{mg} / \mathrm{Kg}$ parenteral Vit C for two times after CLP significantly took a turn for the 


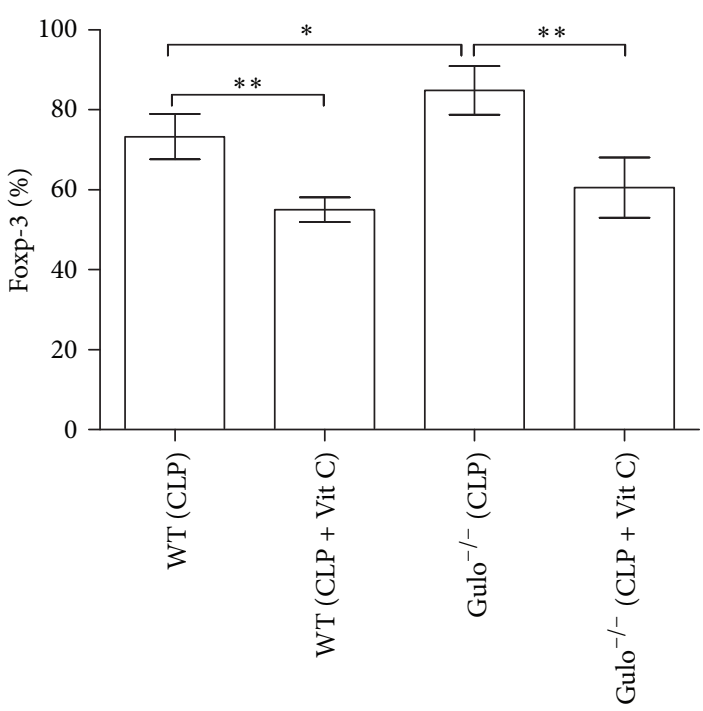

(a)

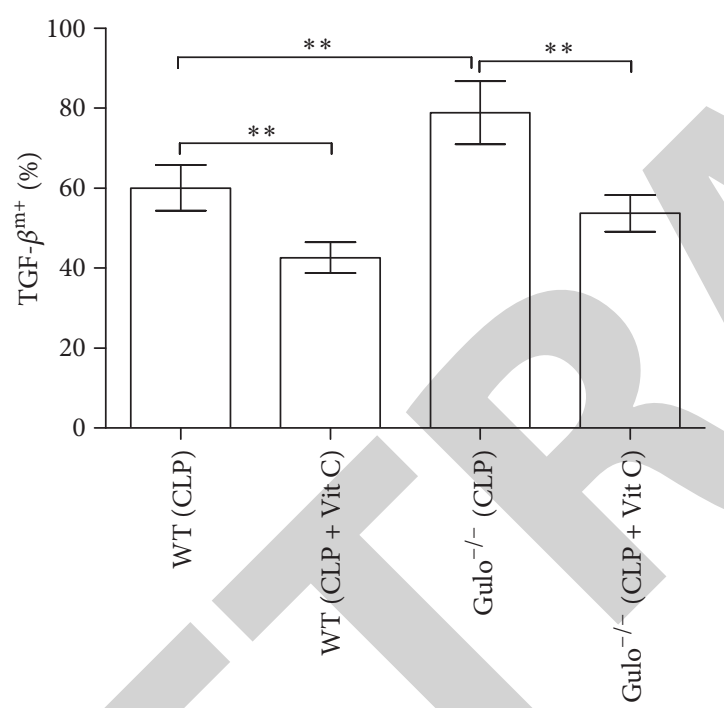

(c)

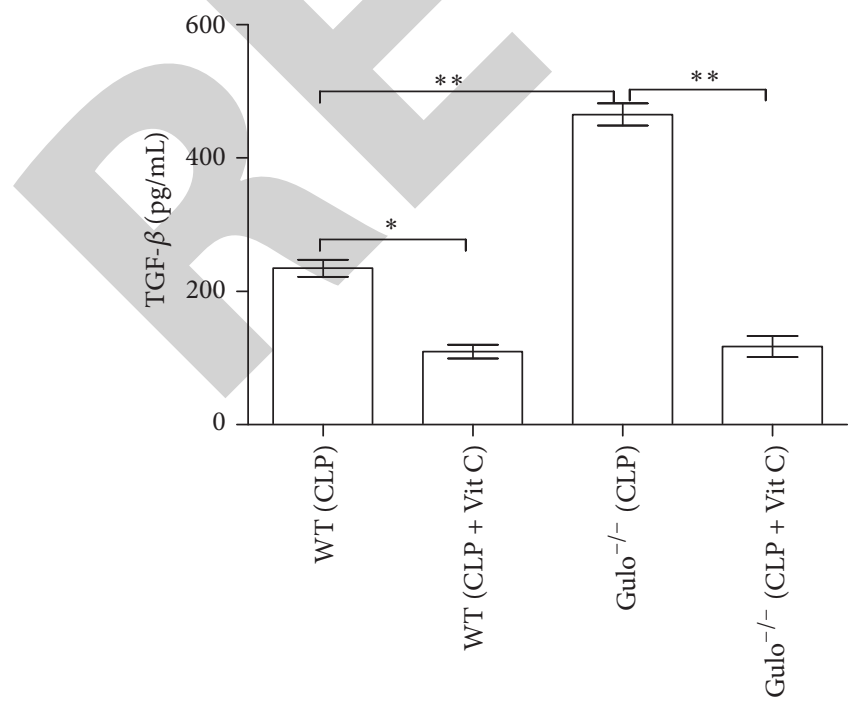

(e)

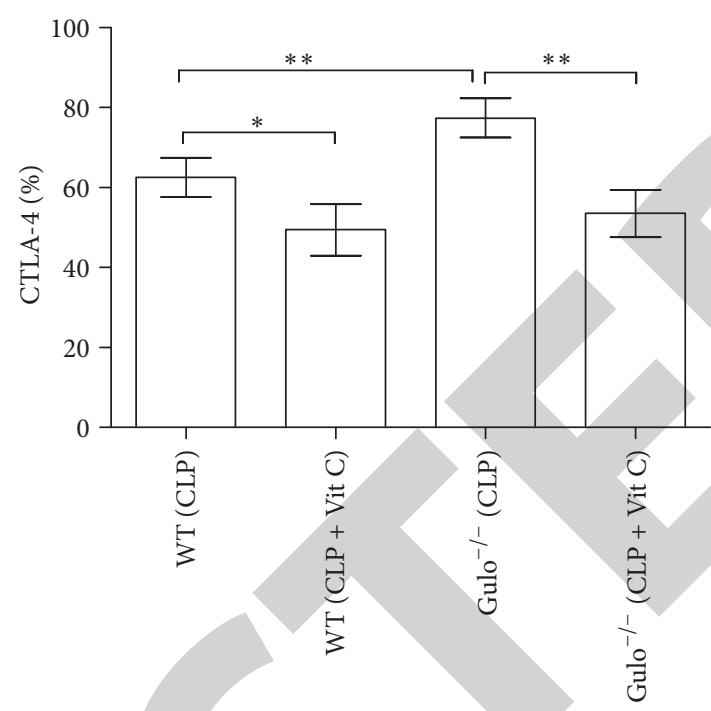

(b)

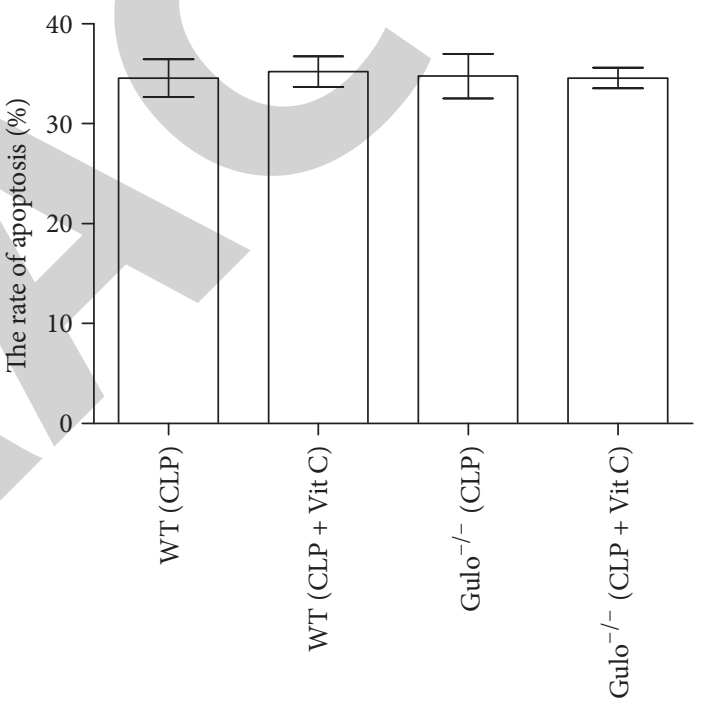

(d)

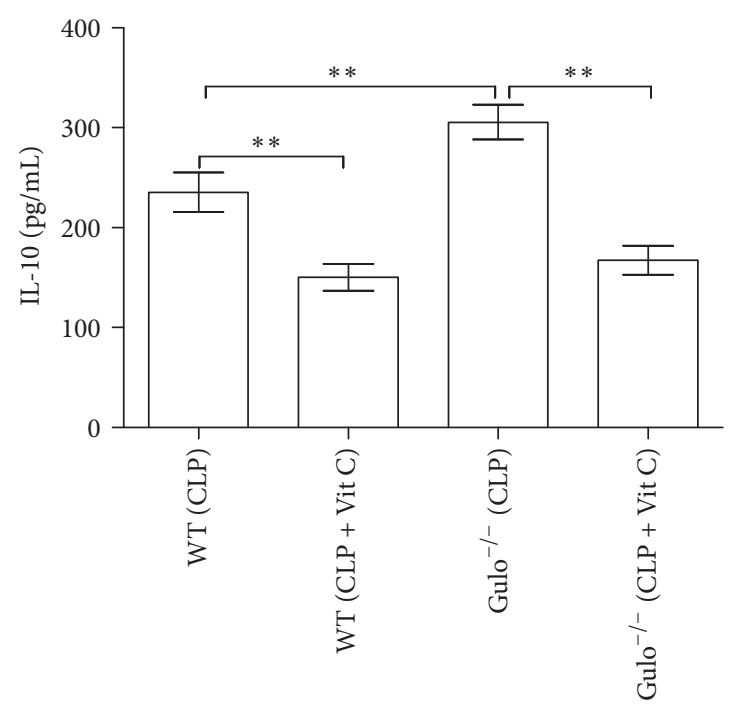

(f)

Figure 2: Continued. 

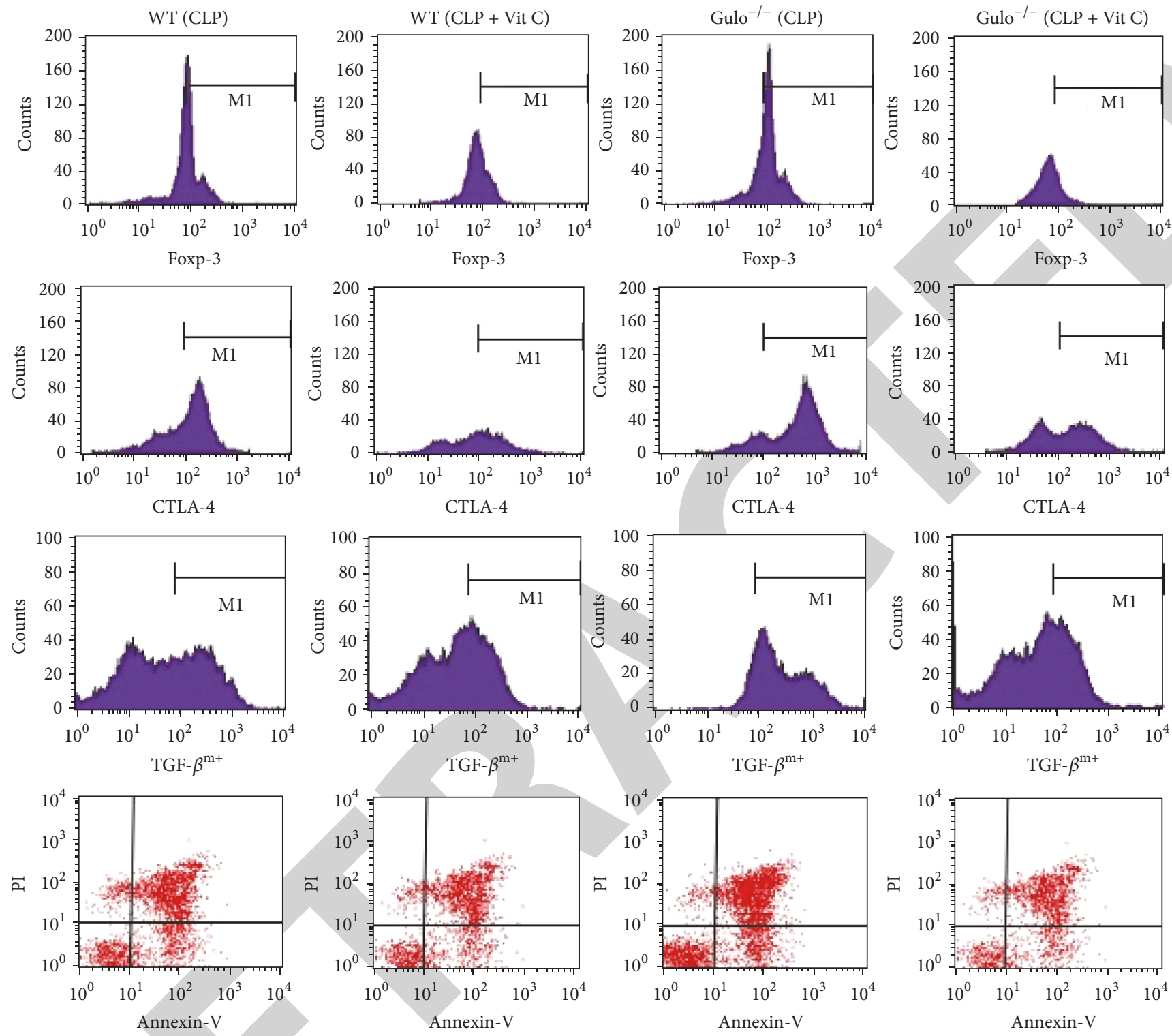

(g)

FIgURE 2: Parenteral Vit C markedly weakened the stability of CD $4^{+} \mathrm{CD} 25^{+}$Tregs in sepsis. The expressions of Foxp-3, CTLA-4, and TGF- $\beta^{\mathrm{m}+}$, as well as the apoptotic ability of splenic $\mathrm{CD} 4^{+} \mathrm{CD} 25^{+}$Tregs, were subjected to flow cytometric analysis by flow cytometer $(\mathrm{g})$. Parenteral Vit C downregulated the expression of Foxp-3 (a), CTLA-4 (b), and TGF- $\beta^{\mathrm{m}+}$ (c) of CD $4^{+} \mathrm{CD} 25^{+}$Tregs in sepsis. Parenteral Vit C did not alter the apoptotic ability of splenic CD $4^{+} \mathrm{CD} 25^{+}$Tregs in sepsis (d). Parenteral Vit C inhibited the secretion of TGF- $\beta$ (e) and IL-10 (f) from $\mathrm{CD} 4^{+} \mathrm{CD} 25^{+}$Tregs in sepsis. Data were represented as mean \pm standard deviation (SD) and analyzed by software SPSS 17.0 with one-way ANOVA, $n=4$ per group, ${ }^{*} p<0.05$ or ${ }^{* *} p<0.01$.

better and acted on upregulating the proliferative response and IFN- $\gamma$ secretion as well as downregulating the apoptotic rate and IL-4 secretion. The immunological mechanisms of Vit $\mathrm{C}$ on $\mathrm{CD} 4^{+} \mathrm{T}$ cells have not been elucidated; reactive oxygen species (ROS) was formed during $\mathrm{CD}^{+} \mathrm{T}$ cells activation which acted as the second messenger [19-21, 27]. We conjectured that parenteral Vit $\mathrm{C}$ affects $\mathrm{T}$ cell behaviors during sepsis via ROS.

We have reported that the percentage and stability of Tregs were higher in septic patients than those without sepsis; a reduction in the stability of Tregs was accompanied by an improvement in survival rate and immune dysfunction of T-lymphocytes with sepsis [12-15, 23, 24]. Foxp- 3, which is still the mainly intracellular marker for identification of Tregs, was also critical for their function, differentiation, and maintenance $[10,11]$. Our previous study demonstrated that an increased expression of Foxp-3 in Tregs was positively correlated to the mortality of septic mice [12]. Parenteral Vit C weakened the expression of Foxp-3 at protein and gene levels, but the deficiency of Vit $\mathrm{C}$ promoted the expression of Foxp-3 


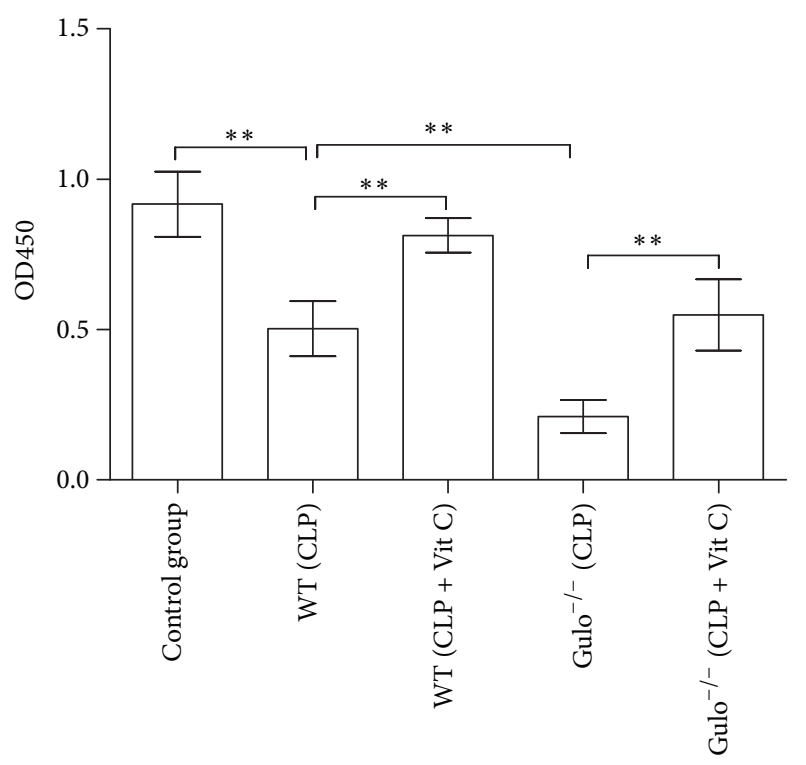

(a)

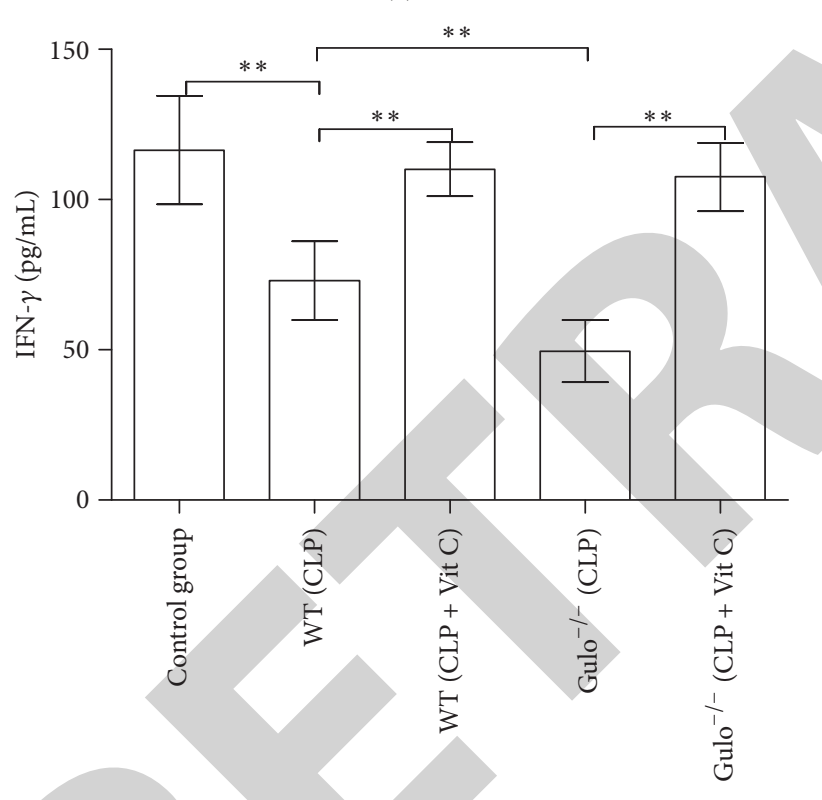

(c)

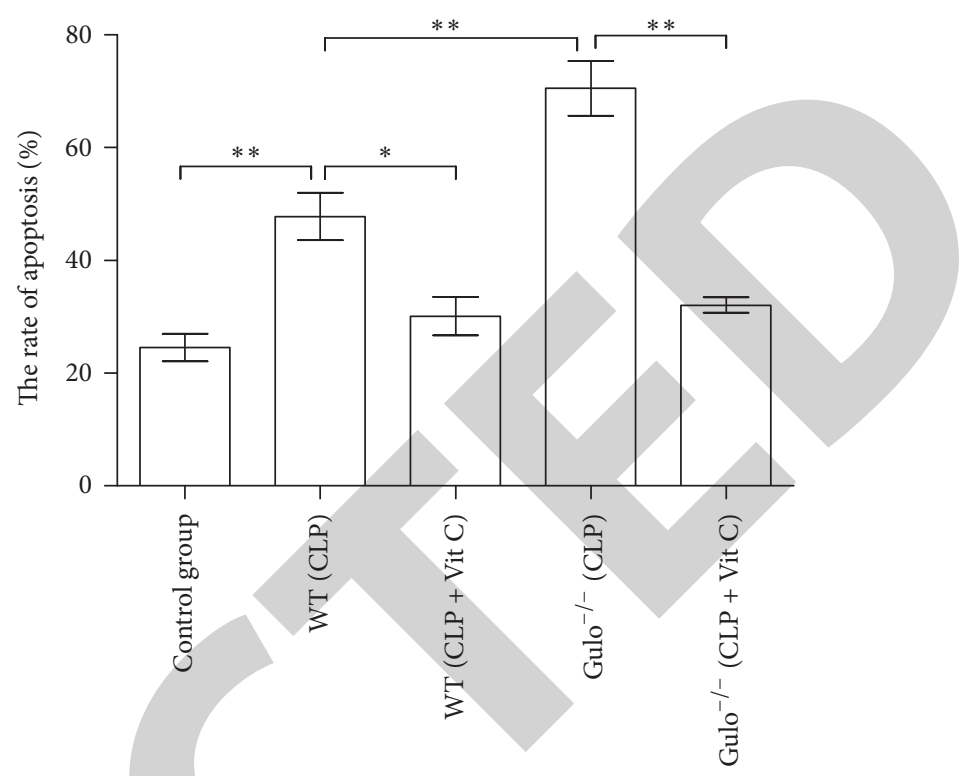

(b)

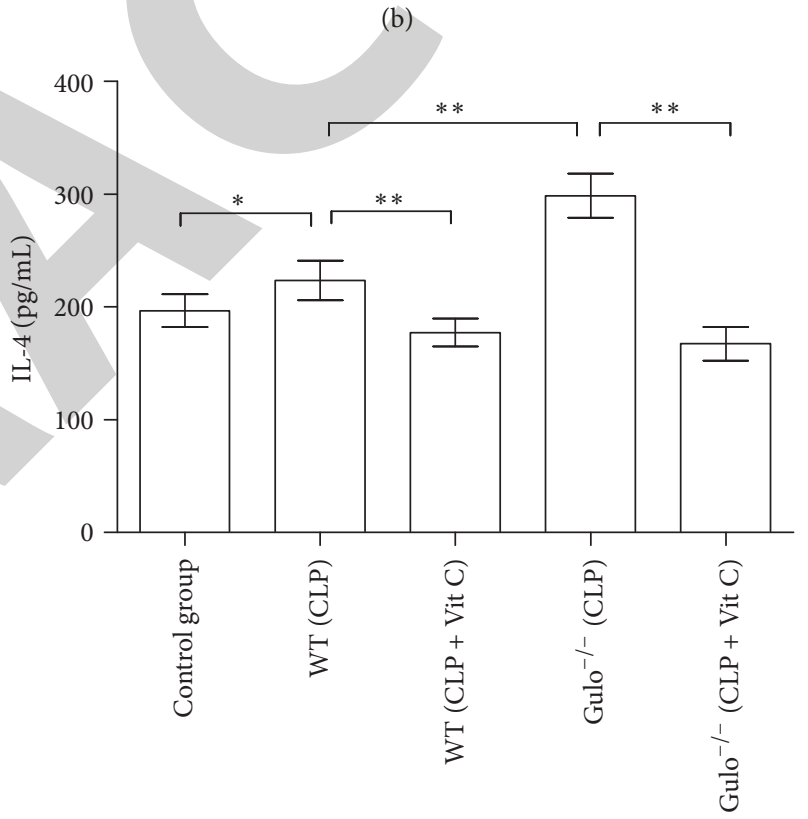

(d)

FIgURE 3: The impact of parenteral Vit $\mathrm{C}$ on the immunosuppressive function of $\mathrm{CD} 4^{+} \mathrm{CD} 25^{+}$Tregs. The parenteral Vit $\mathrm{C}$ inhibited the immunosuppressive function of $\mathrm{CD} 4{ }^{+} \mathrm{CD} 25^{+}$Tregs which upregulated the proliferative response (a) and release of IFN- $\gamma$ (c) but significantly downregulated the apoptotic rate (b) and release of IL-4 (d) of splenic conventional CD $4^{+} \mathrm{CD} 25^{-} \mathrm{T}$ cells. Data were represented as mean \pm standard deviation (SD) and analyzed by software SPSS 17.0 with one-way ANOVA, $n=4$ per group, ${ }^{*} p<0.05$ or ${ }^{* *} p<0.01$.

in $\mathrm{Gulo}^{-1-}$ mice septic model. The recent researches showed that the expression of transcription factor Helios controlled a great deal of pivotal aspects of Tregs' suppressive function, differentiation, and survival [28]. We first reported that sepsis per se promoted the mRNA expression of Helios, especially in the absence of Vit $\mathrm{C}$, but treatment with parenteral Vit $\mathrm{C}$ after CLP of WT and Gulo ${ }^{-1-}$ mice inhibited the mRNA expression of Helios. These suggested that parenteral Vit C had significant ability to decrease the stability of Tregs with sepsis.
During the development of sepsis, Tregs can mainly inhibit the activation of $\mathrm{CD} 4{ }^{+} \mathrm{T}$ cells through various mechanisms, mainly including the pathway of cellular contact (e.g., CTLA-4 and TGF- $\beta^{\mathrm{m}+}$ ) and inhibitory cytokines (e.g., IL10 and TGF- $\beta$ ), as well as upregulating the antiapoptotic ability of Tregs $[11-15,23,24]$. Accumulated evidence has shown that a combination of Foxp-3, CTLA-4, TGF- $\beta^{\mathrm{m}+}$, and inhibitory cytokines (IL-10 and TGF- $\beta$ ) might serve as active markers for Tregs with sepsis. Our previous study demonstrated that sepsis obviously enhanced the negative 


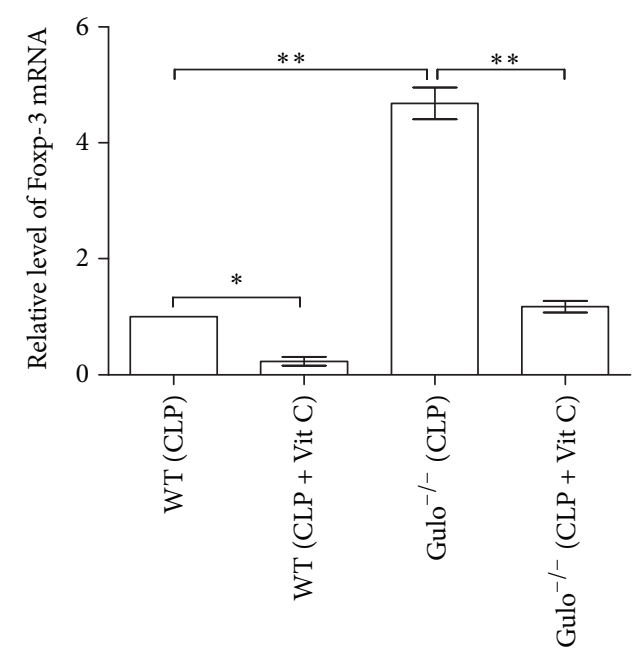

(a)

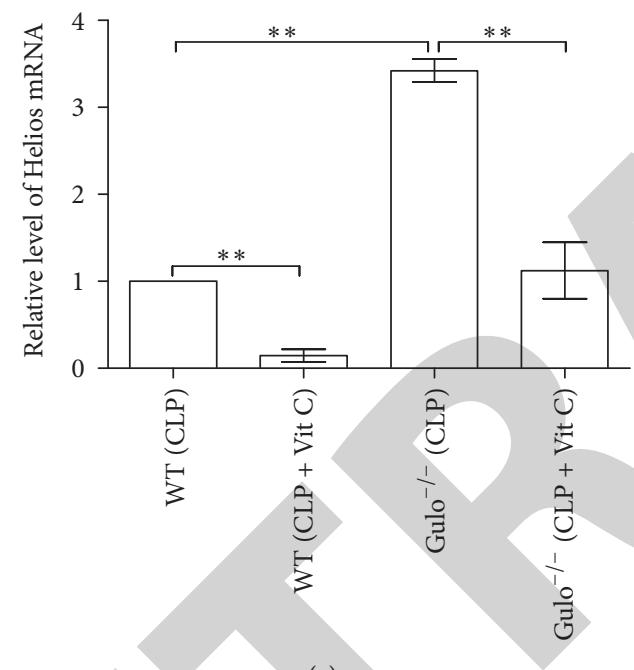

(c)

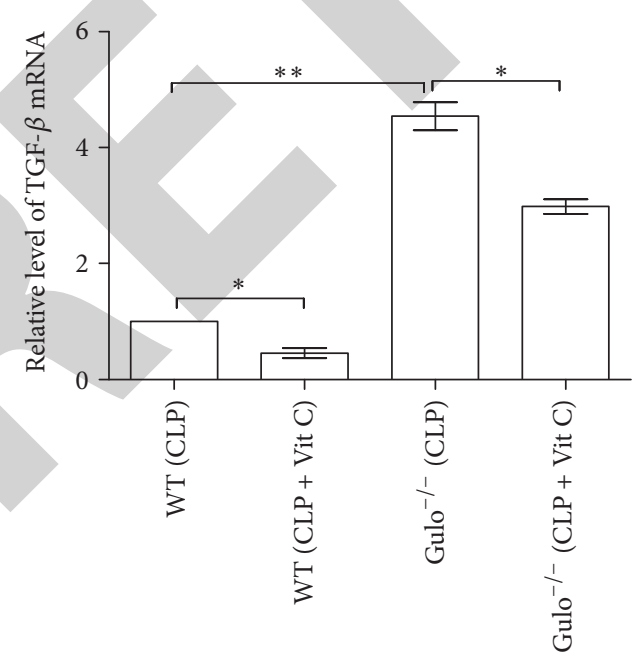

(e)

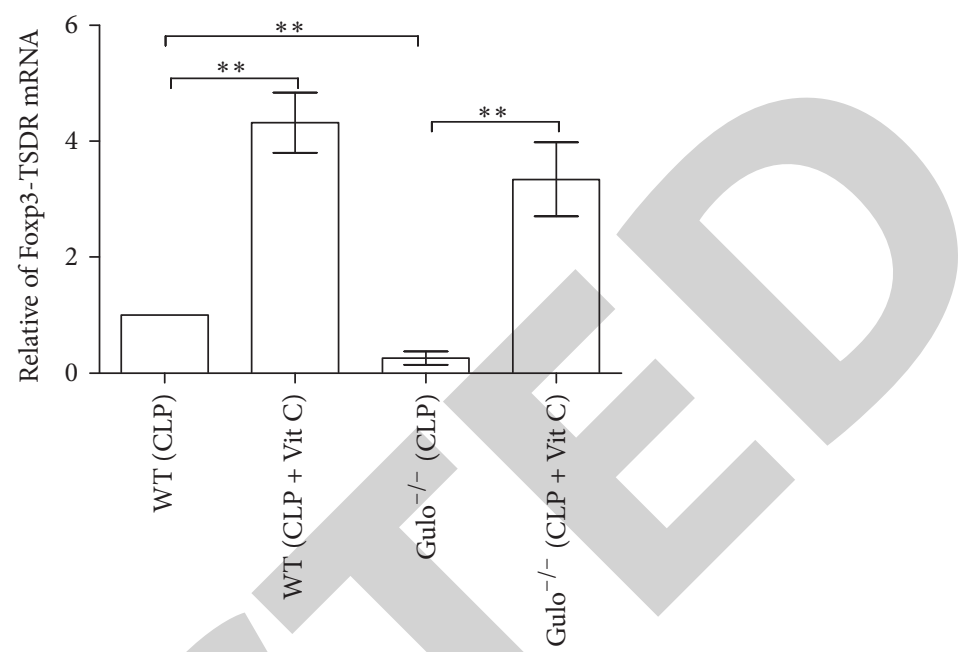

(b)

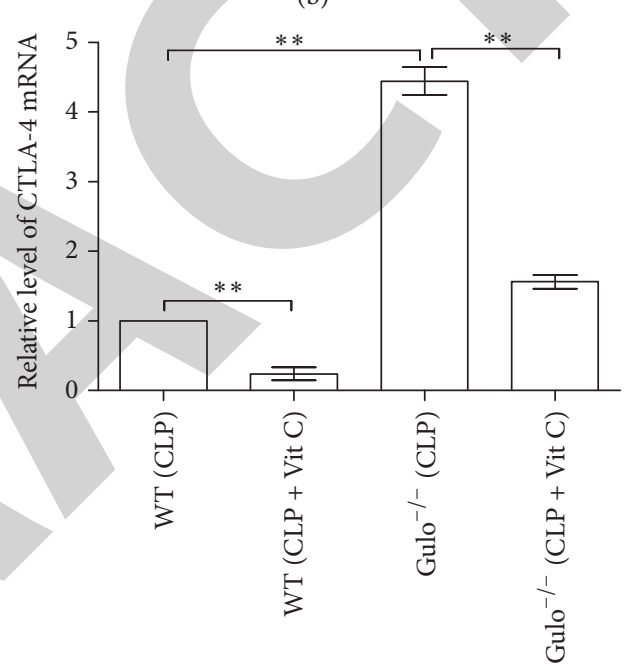

(d)

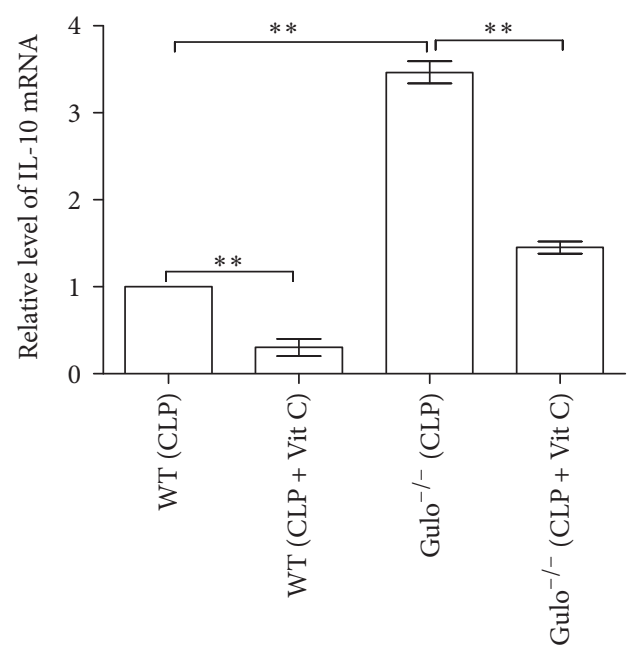

(f)

Figure 4: The impact of parenteral Vit C on the mRNA expression of Foxp-3, Helios, CTLA-4, TGF- $\beta$, IL-10, and the methylation level of Foxp3-TSDR mRNA in $\mathrm{CD}^{+} \mathrm{CD} 25^{+}$Tregs; $\mathrm{CD} 4^{+} \mathrm{CD} 25^{+}$Tregs were harvested for SYBR Green and Methylation-Sensitive RT-PCRT from every group after CLP. The parenteral Vit C inhibited the expression of Foxp-3 (a), Helios (c), CTLA-4 (d), TGF- $\beta$ (e), and IL-10 (f) but increased the methylation level of Foxp3-TSDR (b) in CD4 $4^{+}$DD $25^{+}$Tregs. Data were represented as mean \pm standard deviation (SD) and analyzed by software SPSS 17.0 with one-way ANOVA, $n=4$ per group, ${ }^{*} p<0.05$ or ${ }^{* *} p<0.01$. 


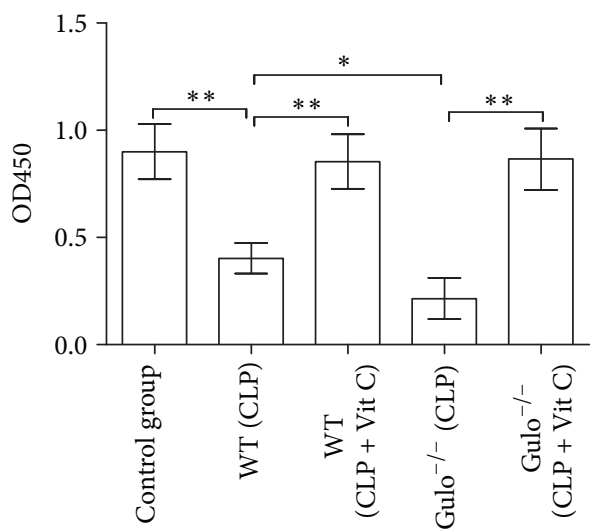

(a)

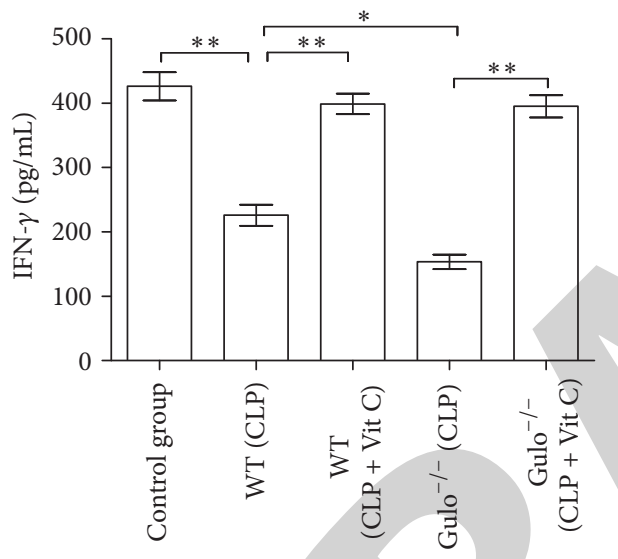

(c)
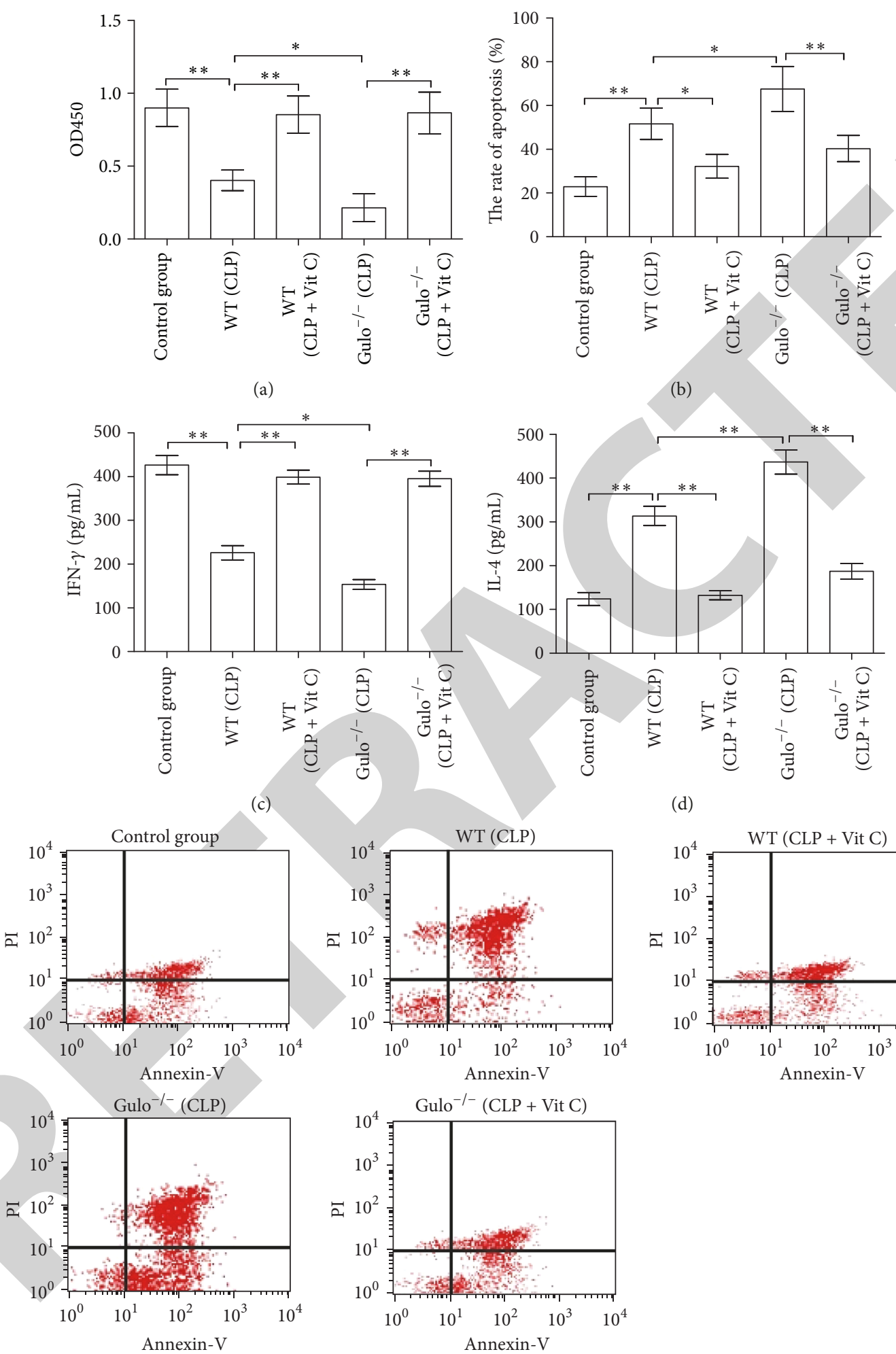

(b)

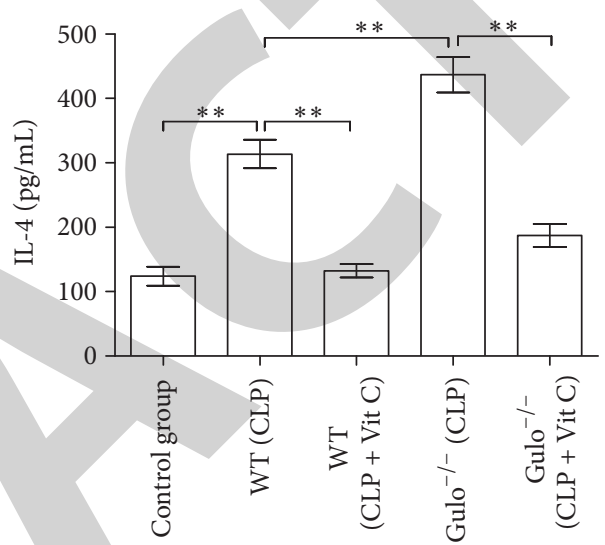

(d)
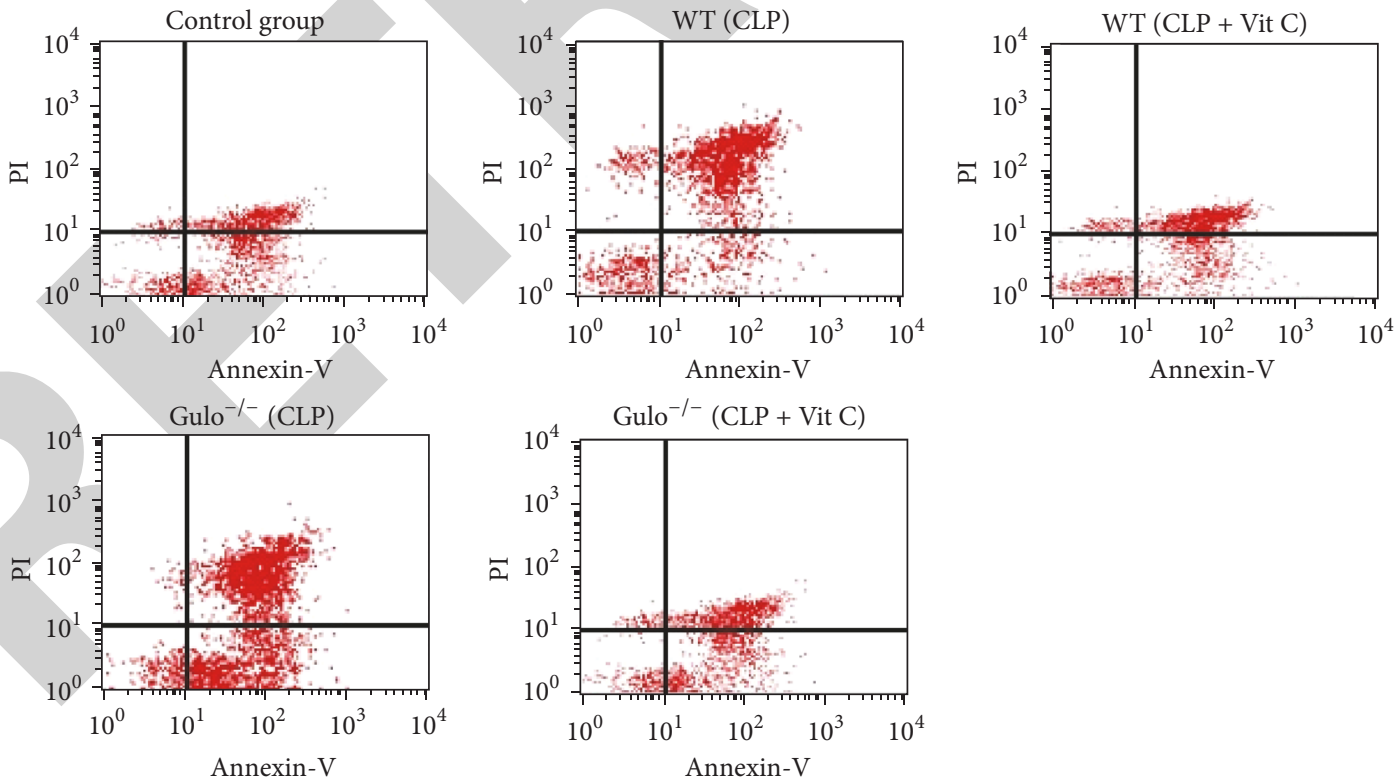

(e)

Figure 5: The impact of parenteral Vit $\mathrm{C}$ on $\mathrm{CD}^{+} \mathrm{T}$ cells-mediated cellular immunosuppression in sepsis. Treatment with $200 \mathrm{mg} / \mathrm{Kg}$ parenteral Vit $\mathrm{C}$ upregulated the proliferative response of $\mathrm{CD} 4^{+} \mathrm{CD} 25^{-} \mathrm{T}$ cells of WT mice and Gulo ${ }^{-/-}$mice in sepsis (a). The apoptotic rate of splenic $\mathrm{CD} 4^{+} \mathrm{CD} 25^{-} \mathrm{T}$ cells was analyzed with Annexin-V-FITC/PI by flow cytometry at 24 hours after CLP-induced midgrade sepsis (e). The apoptotic level of splenic CD $4^{+} \mathrm{CD} 25^{-} \mathrm{T}$ cells was decreased when $200 \mathrm{mg} / \mathrm{Kg}$ parenteral Vit $\mathrm{C}$ was administered after CLP to WT mice and Gulo $^{-1-}$ mice in sepsis (b). Parenteral Vit C increased the serum level of IFN- $\gamma$ (c) as well as decreasing the serum levels of IL-4 (d) of WT mice and $\mathrm{Gulo}^{-1-}$ mice in sepsis. Data were represented as mean \pm standard deviation (SD) and analyzed by software SPSS 17.0 with one-way ANOVA, $n=4$ per group, ${ }^{*} p<0.05$ or ${ }^{* *} p<0.01$. 
immunoregulation of Nrp- $1^{\text {high }} \mathrm{CD} 4{ }^{+} \mathrm{CD} 25^{+}$Tregs which correlated to the expression of Foxp-3 and CTLA-4, as well as the secretion of IL-10 and TGF- $\beta$ [23]. We showed that parenteral Vit $C$ could inhibit the expression of exterior CTLA- 4 and TGF- $\beta^{\mathrm{m}+}$ and the secretion of TGF- $\beta$ and IL-10 at protein and gene levels but did not alter the apoptotic level of $\mathrm{CD}_{4}^{+} \mathrm{CD} 25^{+}$Tregs. These findings were in accordance with the results of our previous studies [12,13]. The stability of Tregs includes the expression of Foxp-3 and negative immunoregulation with sepsis, which is crucially dependent on the demethylation status of the Foxp3-TSDR [11]. Our previous study suggested that recombinant Nrp-1 polyclonal antibody could decrease the demethylation of Foxp3-TSDR in the presence of LPS, which is associated with inhibition of the negative immunoregulation of Tregs [23]. In the current study, parenteral Vit $\mathrm{C}$ had the ability to decrease the demethylation level of Foxp3-TSDR, but the deficiency of Vit $\mathrm{C}$ increased the demethylation level of Foxp3-TSDR in $\mathrm{Gulo}^{-/-}$mice septic model, which was in accordance with our previous findings.

\section{Conclusion}

In conclusion, administration of parenteral Vit $\mathrm{C}$ improved the outcome of sepsis and sepsis-induced MODS of WT and Gulo $^{-/-}$mice. The negative immunoregulation of Tregs was inhibited, mainly including inhibiting the expression of Foxp3 , CTLA- 4 , and TGF- $\beta^{\mathrm{m}+}$ and the secretion of inhibitory cytokines (TGF- $\beta$ and IL-10); CD4 ${ }^{+}$T cells-mediated cellular immunosuppression was improved by parenteral Vit $\mathrm{C}$ in WT and $\mathrm{Gulo}^{-1-}$ septic mice. These results suggested that parenteral Vit $\mathrm{C}$ has the ability to improve the outcome of sepsis and sepsis-induced MODS and is associated with improvement in cellular immunosuppression.

\section{Competing Interests}

The authors declare that they have no competing financial interests. This work is attributed to Tianjin Medical University General Hospital, Tianjin, China.

\section{Authors' Contributions}

Yu-Lei Gao, Bin Lu, and Jian-Hua Zhai contributed equally to this work.

\section{Acknowledgments}

This work was supported by grants from the TMUGH funding (nos. ZYYFY2015020 and ZYYFY2014014) and the Rui-E funding (no. 2016020). The authors thank Professor Shu-Zhang Cui of Emergency Department of Tianjin Medical University General Hospital for the guidance of experimental design.

\section{References}

[1] M. Singer, C. S. Deutschman, C. W. Seymour et al., "The third international consensus definitions for sepsis and septic shock
(Sepsis-3)," The Journal of the American Medical Association, vol. 315, no. 8, pp. 801-810, 2016.

[2] K.-M. Kaukonen, M. Bailey, D. Pilcher, D. J. Cooper, and R. Bellomo, "Systemic inflammatory response syndrome criteria in defining severe sepsis," The New England Journal of Medicine, vol. 372, no. 17, pp. 1629-1638, 2015.

[3] D. F. Gaieski, J. M. Edwards, M. J. Kallan, and B. G. Carr, "Benchmarking the incidence and mortality of severe sepsis in the united states," Critical Care Medicine, vol. 41, no. 5, pp. 11671174, 2013.

[4] B. D. Winters, M. Eberlein, J. Leung, D. M. Needham, P. J. Pronovost, and J. E. Sevransky, "Long-term mortality and quality of life in sepsis: a systematic review," Critical Care Medicine, vol. 38, no. 5, pp. 1276-1283, 2010.

[5] S. Inoue, K. Suzuki-Utsunomiya, Y. Okada et al., "Reduction of immunocompetent $\mathrm{T}$ cells followed by prolonged lymphopenia in severe sepsis in the elderly," Critical Care Medicine, vol. 41, no. 3, pp. 810-819, 2013.

[6] L. P. Skrupky, P. W. Kerby, and R. S. Hotchkiss, "Advances in the management of sepsis and the understanding of key immunologic defects," Anesthesiology, vol. 115, no. 6, pp. 13491362, 2011.

[7] J. S. Boomer, K. To, K. C. Chang et al., "Immunosuppression in patients who die of sepsis and multiple organ failure," The Journal of the American Medical Association, vol. 306, no. 23, pp. 2594-2605, 2011.

[8] C. J. Darcy, G. Minigo, K. A. Piera et al., "Neutrophils with myeloid derived suppressor function deplete arginine and constrain T cell function in septic shock patients," Critical Care, vol. 18, no. 4, article R163, 2014.

[9] K. Chang, C. Svabek, C. Vazquez-Guillamet et al., "Targeting the programmed cell death 1: programmed cell death ligand 1 pathway reverses T cell exhaustion in patients with sepsis," Critical Care, vol. 18, no. 1, article R3, 2014.

[10] D. C. Nascimento, J. C. Alves-Filho, F. Sônego et al., "Role of regulatory $\mathrm{T}$ cells in long-term immune dysfunction associated with severe sepsis," Critical Care Medicine, vol. 38, no. 8, pp. 1718-1725, 2010.

[11] R. Tatura, M. Zeschnigk, W. Hansen et al., "Relevance of Foxp $3^{+}$ regulatory T cells for early and late phases of murine sepsis," Immunology, vol. 146, no. 1, pp. 144-156, 2015.

[12] Q. Y. Liu, Y. M. Yao, Y. Yu et al., "Astragalus polysaccharides attenuate postburn sepsisvia inhibiting negative immunoregulation of CD4+CD25highT cells," PLoS ONE, vol. 6, no. 6, Article ID e19811, 2011.

[13] X.-M. Zhu, Y.-M. Yao, H.-P. Liang et al., "High mobility group box-1 protein regulate immunosuppression of regulatory $\mathrm{T}$ cells through toll-like receptor 4," Cytokine, vol. 54, no. 3, pp. 296304, 2011.

[14] Y. Zhang, Y.-M. Yao, L.-F. Huang, N. Dong, Y. Yu, and Z.-Y. Sheng, "The potential effect and mechanism of high-mobility group box 1 protein on regulatory $\mathrm{T}$ cell-mediated immunosuppression," Journal of Interferon and Cytokine Research, vol. 31, no. 2, pp. 249-257, 2011.

[15] Y.-Y. Luan, C.-F. Yin, Q.-H. Qin et al., "Effect of regulatory T cells on promoting apoptosis of $\mathrm{T}$ lymphocyte and its regulatory mechanism in sepsis," Journal of Interferon and Cytokine Research, vol. 35, no. 12, pp. 969-980, 2015.

[16] B. J. Fisher, D. Kraskauskas, E. J. Martin et al., "Attenuation of sepsis-induced organ injury in mice by vitamin C," Journal of Parenteral and Enteral Nutrition, vol. 38, no. 7, pp. 825-839, 2014. 
[17] P. E. Marik, "'Vitamin S' (Steroids) and Vitamin C for the treatment of severe sepsis and septic shock!," Critical Care Medicine, vol. 44, no. 6, pp. 1228-1229, 2016.

[18] J.-M. Hong, J.-H. Kim, J. S. Kang, W. J. Lee, and Y.-I. Hwang, "Vitamin C is taken up by human T cells via sodium-dependent vitamin $\mathrm{C}$ transporter 2 (SVCT2) and exerts inhibitory effects on the activation of these cells in vitro," Anatomy and Cell Biology, vol. 49, no. 2, pp. 88-98, 2016.

[19] J. Manning, B. Mitchell, D. A. Appadurai et al., "Vitamin C promotes maturation of T-cells," Antioxidants and Redox Signaling, vol. 19, no. 17, pp. 2054-2067, 2013.

[20] S. Mburu, J. L. Marnewick, A. Abayomi, and H. Ipp, "Modulation of LPS-induced CD4+ T-cell activation and apoptosis by antioxidants in untreated asymptomatic HIV infected participants: An In Vitro Study," Clinical and Developmental Immunology, vol. 2013, Article ID 631063, 9 pages, 2013.

[21] P. H. Tan, P. Sagoo, C. Chan et al., "Inhibition of NF- $\kappa$ B and oxidative pathways in human dendritic cells by antioxidative vitamins generates regulatory T cells," Journal of Immunology, vol. 174, no. 12, pp. 7633-7644, 2005.

[22] V. S. Nair, M. H. Song, and K. I. Oh, "Vitamin C facilitates demethylation of the Foxp3 enhancer in a Tet-dependent manner," Journal of Immunology, vol. 196, no. 5, pp. 2119-2131, 2016.

[23] Y.-L. Gao, Y.-F. Chai, A.-L. Qi et al., "Neuropilin$1^{\text {high }} \mathrm{CD} 4^{+} \mathrm{CD} 25^{+}$regulatory $\mathrm{T}$ cells exhibit primary negative immunoregulation in sepsis," Mediators of Inflammation, vol. 2016, Article ID 7132158, 11 pages, 2016.

[24] Y. L. Gao, Y. F. Chai, N. Dong et al., “Tuftsin-derived T-peptide prevents cellular immunosuppression and improves survival rate in septic mice," Scientific Reports, vol. 5, Article ID 16725, 2015.

[25] Z. Yang, Y. Zhang, L. Dong et al., "The reduction of peripheral blood $\mathrm{CD}^{+} \mathrm{T}$ cell indicates persistent organ failure in acute pancreatitis," PLoS ONE, vol. 10, no. 5, Article ID e0125529, 2015.

[26] R. Sharma, P. R. Sharma, Y. C. Kim et al., "IL-2-controlled expression of multiple $\mathrm{T}$ cell trafficking genes and Th2 cytokines in the regulatory $\mathrm{T}$ cell-deficient scurfy mice: implication to multiorgan inflammation and control of skin and lung inflammation," The Journal of Immunology, vol. 186, no. 2, pp. 12681278, 2011.

[27] M. J. A. J. Huijskens, M. Walczak, N. Koller et al., "Technical advance: ascorbic acid induces development of double-positive $\mathrm{T}$ cells from human hematopoietic stem cells in the absence of Stromal cells," Journal of Leukocyte Biology, vol. 96, no. 6, pp. 1165-1175, 2014.

[28] H.-J. Kim, R. A. Barnitz, T. Kreslavsky et al., "Stable inhibitory activity of regulatory $\mathrm{T}$ cells requires the transcription factor Helios," Science, vol. 350, no. 6258, pp. 334-339, 2015. 